\title{
Napló a hálózati tanításról
}

A Nyugat-Magyarországi Egyetemen szervezett eLearning kísérlet az internettel támogatott oktatásra épült. Mivel az előzetes tudás szintjei és a konkrét cselekvési igények az egyes tanulók esetében nagyon különbözőek lehetnek, nem lehet minden résztvevő számára kötelező vagy elvárható utakat előírni. Emiatt a függő változókat a képzési idő és az elágazó, projekt-jellegű, kollektív tudástermelésen alapuló tanulási utak jelentik. A kísérlethez választott módozatban a kimeneti eredmény egységes volt, mivel minden hallgató olyan jellegű elágazást választhatott, amelyet saját előzetes tudásának figyelembe vétele megkövetelt, $s$ annyi időt fordíthatott a tanulásra, amennyi a saját tanulási stílusának és a saját tempójának a legjobban megfelelt. A kitűzött célok és a megvalósult projekt közötti különbségek jó része abból fakadt, hogy kötött időbeli és erőforrásbeli korlátok között kísérleteztek olyan tanulási formákkal, amelyek rugalmas időbeli kereteket igényelnének, és új együttműködési formák alkalmazását, a tanulás, a tudás és a tudáselosztás újradefiniálását kívánnák meg.

\section{Szerzői információ:}

Bessenyei István

A debreceni egyetemen 1969-ben tanári diplomát szerzett, majd 1978-ban az ELTE szociológiai szakán doktorált szociológiából. Az ELTE szociológiai tanszékén volt adjunktus, majd az Országos Közoktatási Intézet kutatási központjában oktatáskutatással foglalkozott. 1997-ben kapta meg a PhD fokozatot. 2001-tól a Nyugat-Magyarországi Egyetem docense. Szakterülete: az internet hatása az oktatásra és általában az informatizálódás társadalmi hatásai.

Így hivatkozzon erre a cikkre:

Bessenyei István. „Napló a hálózati tanításról”.

Információs Társadalom V, 3. szám (2005): 47-62.

$=$ https://dx.doi.org/10.22503/inftars.V.2005.3.4 $\rightleftharpoons$

A folyóiratban közölt müvek

a Creative Commons Nevezd meg! - Ne add el! - Így add tovább! 4.0

Nemzetközi Licenc feltételeinek megfelelöen használhatók. 
Bessenyei István

\section{Napló a hálózati tanításról'}

A hálózati tanulás - az eLearning - számomra a kikényszerített, szakmányban való tanulásból való kilépés és a szubjektív tanári hatalom alóli felszabadulás esélyét jelentette. A kötelezô, előre megadott összefüggések helyett az adatok, információk és tudáshalmazok közötti kószálás és a választás posztmodern szabadságát. Azt a lehetốséget, hogy az internet által elérhetố információk és a kontextusok sokféleségéból a saját életgyakorlatom és eddigi tudásom, tapasztalati anyagom segítségével magam alkossak felhasználható tudást.

Mindez megtehetô volt az individualizált, autodidakta, öntovábbképzô, önszervezó, nem bürokratikus keretek között folyó felnốttkori tanulás alaphelyzetében. De hogyan múködik a dolog az iparszerú, tömegtermelésre beállított intézmények viszonyai között? Elképzelhetốe az individualizált tanulási utak rendszere, az előzetes tudások számbavétele, a kontextusközlés helyett a kollektív kontextuskeresés és kontextusalkotás, a kooperatív tudástermelés a futószalag-rendszer paradigmáit máig oórzố intézmény - az egyetem - mai feltételei mellett?

\section{A hálózati tanítás kihívása}

Az internettel támogatott tanítási kísérletünk három évvel ezelốtt kezdődött. ${ }^{2}$ A hiú remény, hogy az új technológiával tanítási idốt és energiát lehet megtakarítani, hamar szertefoszlott. Az internettel kísért oktatás („,blended learning”) ugyanis intenzív kommunikációt feltételez tanár és diák között. A hierarchikus tudáselosztás - amelynek mintaformája a hagyományos elóadás - felülról lefelé irányul, nem interaktív. Hagyományos szemináriumi keretek között a vita és a kommunikáció limitált térbeli és idóbeli keretek között zajlik (legfeljebb a dolgozatok otthoni javítása lépi át a zárt térbeli határt). Az új kommunikációs eszközök e határokat kiterjesztik. A tanár az elektronikus postával mindenütt elérhetố. A tananyag (akár a tanár előadása is) - csakúgy, mint a diákok internetes munkája - a világ bármely internetes munkaállomásáról követhetố és kommentálható.

\footnotetext{
${ }^{1}$ A tanulmány tapasztalati alapjául szolgáló kurzusok szervezése és a tanulmány megírása az Információs és Hírközlési Minisztérium támogatásával volt lehetséges. A minisztérium támogatásával jött létre a Nyugat-Magyarországi Egyetemen is az Információs Társadalom Oktató és Kutató Csoport (ITOK), amelynek keretében az internetes tananyagfejlesztés és a tapasztalatok feldolgozása történt. Ilyen csoportok - az Információs Társadalom- és Trendkutató Központ szervezésében - már több mint egy tucat egyetemen alakultak meg.

2 „Tưdásgazdaságtan és tudásmenedzsment” választható, német nyelvû kurzus elsốéves közgazdász hallgatóknak, „Informatika-gazdaság-társadalom” negyedéves, gazdasági informatikára szakosodott közgazdász hallgatóknak, „e-kommunikáció” elsóéves, másodéves és harmadéves közgazdász hallgatóknak. (A kurzusok tematikáit részletesen lásd: http://members.chello.at/i.bessenyei/kurse.htm )
} 
Ha azonban egy átlagos egyetemi oktató akár csak heti két csoporttal is internettel támogatott órákat tart, ez negyven hallgatót és potenciálisan heti negyven elektronikus postán is feltehetố kérdést jelent. Ha a hallgatók hetente oldanak meg feladatokat és azokat az integrált oktatásszervezố szoftver segítségével dokumentálják is, az hamarosan több tucatnyi értékelendő feladat elektronikus megérkezésével jár.

Így ütköztünk bele hallgatóinkkal abba az elemi ellentmondásba, hogy ha a háló-

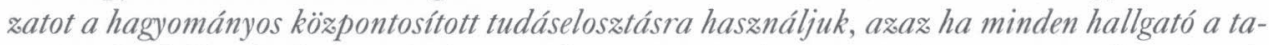
nárhoz fordul kérdéseivel és minden, a tudás megszerzésében megtett lépést a tanár ellenôriz, akkor az rövid úton kezelhetetlen információs közlekedési dugóhoz vezet.

Mi lehet azonban e tudáselosztási mód alternatívája? Csakis az, ha szakítunk az egyirányú, lineáris tudásközlés sémáival és hálózati kapcsolatokban gondolkodunk. Hálózati tanulás egyrészt az, ha a diákok megtanulják, hogyan kell kérdéseikre az internet által felkínált forrásokból feleletet válogatni, dokumentálni, rendszerezni. Hálózatosodásról másrészt akkor beszélhetünk, ha a diákok egymás tudását is forrásként használják, $\mathrm{s}$ egymáshoz is fordulnak információért. A hálózatosodás ezen kívül a sæakértók más csoportjának az oktatási folyamatba való bekapcsolását is feltételezi. Ez a társegyetemek hálózatba szervezésének szükségességét is jelenti.

Ez a következtetés természetesen új kérdések sokaságát vetette fel.

- Rendelkeznek-e a hallgatók olyan (akár informális, rejtett, tapasztalati) tudással, amely a kurzus tematikájába illik?

- Nekik kell-e igazodni a kurzushoz, vagy a kurzusnak az ő előzetes ismereteikhez?

- Hogyan lehet egymástól tanulni (sốt hogyan lehet tanítani), ha nincs reprezentálva a személyes tudás? Lehetséges-e a jelen szervezeti keretek között olyan intenzív munka, hogy elő́llítsunk olyan egyéni kompetencia-portfóliókat, tudástérképeket, amelyek alapján a diákok egymást mint tudásforrást igénybe vehetik?

- Hogyan teremthetünk lehetốséget arra, hogy más „kốegyetemek” tanárait, diákjait is bekapcsoljuk a hálózati tanulás kooperatív tudástermelésébe?

- Hogyan alakul a tanár szerepe egy ilyen múködési módban?

- Alkalmas-e egy ilyen tanítási mód arra, hogy a bürokratikusan lehatárolt vizsgakövetelményeknek meg tudjon felelni a diák?

- Alkalmas-e a mai magyar egyetemi rendszer arra, hogy ilyen intenzív, egyénre szabott oktatást befogadjon?

- Mit is jelent végül is a „tudás”, amit át kell adnunk?

- Hogyan lehet feloldani azt az ellentmondást, hogy a tanítási módszerek szorosan a tantervekhez kötöttek, a jelenlegi tantervek viszont nem támogatják a kísérleti projektek szervezését?

\section{A tudástérkép-projekttől a hálózati kommunikációig}

Ha tehát komolyan vesszük a kooperatív, hálózati tanulást, és azt, hogy a diákok egymást is tudásforrásként használják (s más egyetemek szakértốit is bevonjuk a tutorálásba), akkor ehhez egy olyan szakértói kompetencia-portfólió rendszert kell rendelni, amelynek segítségével a tudásforrás jól dokumentált és mindenki által elérhetô. Ez jól kiépített belsố tudásmenedzsment-bázist feltételez, sốt azt is, hogy a többi egyetem (technikai értelemben is) része a tudáshálózatnak. 
Úgy találtuk, hogy a hálózati kapcsolatok ilyen logisztikájához elengedhetetlenül szükséges, hogy minden részvevố egyéni (szakértói) tudástérképpel, kompetenciaportfólióval rendelkezzék. (A tudásmenedzsment és tudásgazdaságtan szemináriumok profiljába egyébként is illett egy ilyesfajta tevékenység.) Azt a projekt-feladatot kapták tehát a hallgatók, hogy készítsék el egyéni tudástérképüket.

Mi kerüljön be ebbe a tudástérképbe? Hogyan ragadható meg, hogyan rögzíthetố a mások számára is használható tudás? Hogyan kezdjünk hozzá olyan önreflexióhoz, ami felszínre hozza, explicitté teszi a hétköznapi tapasztalatokat, az informális úton szerzett, rejtett tudást? Hogyan artikuláljuk, hogyan fogalmazzuk meg ezt? Ilyesfajta múveletekben kevés gyakorlatunk volt.

Az online szakirodalomban rábukkantunk olyan anyagokra, amelyek a narratív tudásmenedzsmentról szóltak. ${ }^{3}$ A narratív tudásmenedzsment segítségével az elbeszélések elemzése révén fel lehet fedni az egyéni és szervezeti rejtett tudásokat. A hallgatók bemutatkozásai bizonyultak Az elsố ilyen elbeszéléseknek. Az élettapasztalatok egész tárháza tárult fel e narratívák során. Volt, aki fél évig az USA-ban dolgozott egy drogériában. Többen szereztek külföldi egyetemen tapasztalatot. Egy diáklány Franciaországban dolgozott bébiszitterként, egy diák a diákönkormányzat elnöke volt. Volt, aki apja autószerelố múhelyében segédkezett, sốt akadt olyan is, aki saját vállalkozást vezetett. Az egyik diáklány egy elsố osztályú kosárlabdacsapat menedzselésében segített. A hobbik felól is közelítettük a kérdést: a zenei, irodalmi, gyújtối, sportbeli, amatôr múvészeti tapasztalatokat viszonylag könnyen konvertálhattuk kompetenciákká. Akinek semmi ilyen „extra” nem jutott eszébe, azt arra próbáltuk motiválni, hogy iskolai vagy otthoni háztartásszervezési, netán barkácsolási tapasztalatait próbálja kompetencia-kategóriákban kifejezni.

A másik segítséget a tudástérképek elkészítéséhez az jelentette, hogy segédeszközöket (úgynevezett csekklistákat, meglévő tudástérképeket, útmutatókat) kerestünk. ${ }^{4}$

Mindezek alapján közös munkával elterveztünk egy kompetencia-portfólió táblázatot, amely azt a célt szolgálta, hogy vezetố legyen a saját egyéni tudástérképünk elkészítésében, s így a laza életrajzi narratíváknál rendszerezettebb, explicitebb, jobban dokumentálható tudásforráshoz jussunk. ${ }^{5}$

Tudtuk-e használni e tudástérképeket az együttmúködő tudástermelés, az egymástól való tanulás eszközeiként az egyirányú tanár-diák kommunikáció feloldására, a tanár mint tudásforrás tehermentesítésére? Ez a lehetôség az elsố kísérleti félévben még kihasználatlan maradt. A tudástérkép közös elóállítása tartalmazott ugyan kooperatív elemeket, de nem szolgált kölcsönös szakértối tudásbázisként. Miután a rejtett tudások feltárása, a hétköznapi tapasztalatok tudásként való elismertetése, a tudásszintek analitikus tisztázása vitte el az idő nagy részét, a valódi csere motiválására, megszervezésére már nem maradt energia. Az elsóéves, elsố félévüket töltố közgazdász diákok a hétköznapi és,,rejtett” - vagyis nem strukturált - tudásuk explicitté tételében, megfogal-

\footnotetext{
${ }^{3}$ Az objektív hermeneutika módszerével élve, a nem irányított elbeszélések szövegeinek szekvenciális elemzésével meglepő részletességgel lehet elemezni a rejtett tudások szerkezetét.

${ }^{4}$ Saját tudástérképemet lásd: http://titanic.nyme.hu/ itok/fo_osszetevok/tart_resz_oldalak/Tudasterkep.ppt
} 
mazásában gyakorlatlanok voltak, a tapasztalati tudás rendezett fogalmakba öntése igencsak nehéznek bizonyult.

Másrészt nem is tudtam felkínálni olyan projekteket, amelyekbe az egymástól való tanulás, a kompetencia-katalógusok élő használata szervesen illeszkedhetett volna. Nem sikerült arra sem motiválni óket, hogy kommentálják egymás feladatmegoldásait. (Spontán kialakult viszont az a rendszer, hogy az internetes keresésben gyakorlottabb hallgatók eredményesen segítettek a kezdő keresóknek.)

Tudtam-e arra is használni a tudástérkép-projektet, hogy az így kapott információk alapján elốzetes tudásra alapozó egyéni tanulási utat jelöljek ki diákjaimnak? Ez a terv is illúziónak bizonyult. Ehhez egészen más logisztikára, más szervezeti formára lett volna szükségünk, mint ami az adott keretek között megvalósítható volt.

Pedig saját kurzusainkon belül viszonylagos szabadságot élveztünk: nem fenyegetett az, hogy valamilyen vizsgán bárki is tételesen számonkéri azt, hogy mit tanultunk. Elvileg tehát - saját óráinkon - radikálisan szakíthattunk a lineáris modellel. Ugyanakkor a hipertanulás lehetséges útjait mégiscsak kemény idóbeli, térbeli és erôforrásbeli korlátok határozták meg. Erre módszertanilag sem voltunk igazán felkészülve. Nem volt mód önértékelố tesztek kitöltésére, elágazó, többfokozatú tanulási utak használatára. Nem volt mód arra, hogy az egyéni haladási sebességeket ténylegesen figyelembe vegyük.

\section{Az önszervező tanulás mint együttmüködő tudásmenedzselés}

A definíciós és a procedurális tudás közötti különbségtétellel nemcsak azért foglalkoztunk, mert ez szerepelt a tematikánkban, hanem kifejezetten gyakorlati szempontból is. Ahhoz, hogy tudatosan reflektáljuk saját tevékenységeinket, szükségünk volt a tudás és a tanulás fogalmainak pontosabb kibontására is.

A jel, az adat, az információ, a tudás és a kompetencia közötti különbséget úgy határoztuk meg, hogy a kontextusok mibenlétét és logikai rendjét, valamint cselekvésre való átválthatóságát tekintettük a legfontosabb megkülönböztetố tényezóknek. ${ }^{6}$ A szokványos tudáslépcsó ezt így ábrázolja:

\footnotetext{
${ }^{5}$ Az ellenôrzó listákat és a kompetencia-portfóliót lásd: http://kubus.net/moodle/eLearning/melleklet.htm

${ }^{6}$ A tudás meghatározásának számtalan más módja is lehetséges. Lehetséges a tudást explicit vagy implicit mivolta alapján osztályozni („,elózetes tudás”, rejtett tudás, tacit knowledge). A kompetenciát gyakorlati tudásként, az elemzố képességet elméleti tudásként határozzák meg. A folyamatra hangsúlyt helyezố tanulás eredményét orientációs tudásnak is nevezik. Egy másik tudás-osztályozás:

A tudás integratív felfogása szerint a tudás három fố formáját kell fejlesztenünk: a) a tényekkel kapcsolatos tudást - ismeretek, b) a cselekvésekkel kapcsolatos tudást - képességek, $c$ ) a cselekvések tervezésével és kontrolljával kapcsolatos tudást (metakogníció) (Csapó, 1992. 52. o.)” Idézi Pálvölgyi 2003.
} 


\begin{tabular}{|l|l|l|l|}
\hline & & & kompetencia $^{7}$ \\
\hline & tudás & \\
\hline & információ & $\begin{array}{l}\text { + cselekvésbe váltás, alkalmazási } \\
\text { képesség }\end{array}$ & \\
\hline & Adat & kontextus, tapasztalati reflexió & \\
\hline jel & jelentés & & \\
\hline + szintaxis & & & \\
\hline
\end{tabular}

A tudáslépcsốnek ezek a fokozatai rímelnek a személyes tanulás öt lépcsőfokára:

\section{A személyes tanulás öt lépcsófoka}

1. tapasztalás

2. reakció

3. logikai keretbe rendezés

4. megvalósítás, kísérlet

5. ellenőrzés
adat, információ
kontextuskeresés
tudás
kompetencia
visszacsatolás

A tanulásban is rendelkezni kell azzal a minimális szintaktikai képességgel, hogy a jeleket egyáltalán felfogjuk, hogy az adatoknak jelentést tudjunk tulajdonítani. A tanulás másrészt nem más, mint az információk logikai rendszerbe való helyezése, illetve gyakorlati alkalmazása.

A tanulást tehát fel lehet fogni integrált tudásmenedzselésként is. Így jutottunk el ahhoz, hogy a magunk számára meghatározzuk, miként is nézhetne ki a tudásmenedzsmenten alapuló tanulás/tanítás ideáltipikus csekklistája:

1. az információkat felkutatni, érzékelni, feldolgozni, reflektálni és értékelni;

2. az információkat összefüggésekbe helyezni, s így az információkból tudást alkotni;

3. a tudástartalmakat elraktározni valamilyen kollektív emlékezetben;.

4. a tudástartalmakat másoknak átadni, közvetíteni és elosztani;

5. a tudástartalmakat másokkal kooperatív módon megosztani és kölcsönösen kiegészíteni;

6. a tudást alkalmazni, cselekvésre váltani;

7. a tudásra alapozott cselekvést értékelni (reflektálni);

8. elsajátítani a fenti részfolyamatokat;

9. a tudást ápolni vagyis aktualizálni, szúrni és strukturálni;

10. új tudást létrehozni;

11. megszervezni a tudástranszfert, létrehozni és múködtetni a tudástranszfer-hálózatot. (Vö. Chott: 1999)

Milyen tanulási formákat feltételez az együttmúködố tudásmenedzselésen alapuló, önszervezố tanulás?

${ }^{7}$ A hétköznapi nyelvhasználat általában nem különbözteti meg a tudást és a kompetenciát. Ennek egyik alapja az, hogy az intellektuális cselekvés is cselekvés, így tehát a tudás és a kompetencia valójában nehezen elválasztható fogalmak. Másrészt az adat, az információ, a tudás és a kompetencia között végeredményben csak a kontextualizáltság fokában van különbség, ami ismét a hétköznapi nyelvhasználat jogosságát bizonyítja. 
Projektjeinkben közös munkával honlapot hoztunk létre egy olyan fiktív kisvállalkozás számára, amely tudásmenedzsmentet kínál fel kis-és középvállalatoknak. Létrehoztunk egy lexikont a tudásgazdaságtan és a tudásmenedzsment témájában. Értékeltük a globalizációellenes szervezetek honlapját, párhuzamba állítottuk a globalizáció ellen és a globalizáció mellett szóló érveket, és dokumentáltuk a vitát. Saját tudástérképeket készítettünk. Az internetes keresésekról keresési naplót vezettünk. Gyakoroltuk az online kommunikációt. Kezeltünk egy tudásmenedzsment-rendszert. Mindezt az együttmúködő csoportmunkára alapoztuk.

Ezek mind nehezen standardizálható, variábilis, közös tevékenységi formákra építő, sokoldalú egyéni tanulási utakat feltételező múveletek voltak.

E tanulási folyamat legfontosabb újdonsága az volt, hogy a tudásrekonstrukcióról átváltottunk a tudáskonstrukcióra. Nem az adatok, az elóre elrendezett tudáskontextusok reprodukálása volt a cél, hanem az önálló tudástermelés. A metaképességek kerültek elơtérbe: a keresés, a kooperáció és a kontextusok kiválasztása - a gyakorlat reflektálása és a kognitív logika alapján.

A keresés, rendszerezés közben a hallgatóknak önálló munkával kellett rendszerezniük, dokumentálniuk a tárgy egész sor alapfogalmát. Tanulásukra a procedurális tudás megszerzése volt jellemzó. A hangsúly nem a megismert fogalmak definíciójára került, hanem arra, hogy hogyan kell önállóan keresni a definíciókat, hogyan kell ezeket rendszerezni és dokumentálni, hogyan kell a kontextusok keresése közben ezekhez hozzányúlni. Ha arról volt szó, hogy más információk összefüggésbe helyezése céljából szükségünk volt a definícióra, akkor azt a közös munkával létrehozott lexikonból gyorsan elố tudtuk keresni.

A tudás szervezésének, rendszerezésének és dokumentálásának új útjait tapasztalhattuk meg. A hallgatók az internettel támogatott tanulás menetében - mintegy mellesleg - megtanultak kezelni egy komplex tanulási keretrendszert (tulajdonképpen egy tudásmenedzsment-eszközt) is. Ez az integrált tanulási platform tartalmazta az oktatásszervezéshez szükséges folyamat minden elemét: a tananyagszerkesztốt, az adatbáziskezelőt, a kurzusok szervező oldalait, a hallgatói adminisztrációt (beleértve az egyéni oldalakat is), a rendkívül sokoldalú kommunikációs lehetôségeket (fórumokat, chat-tereket, hírcsoportokat), az automatikus feladatgenerálás és az ellenôrzés eszközeit, valamint a diáktevékenységek statisztikai leképezését. ${ }^{8}$

Az önszervezố tanulásra alapozó, internettel támogatott oktatási program felépítését azzal kezdtük, hogy elsónek a tanulási célokat, az elérendó kompetenciák listáját határoztuk meg. Egy ilyen kompetencia-lista szolgálhatott ugyanis arra, hogy az önszervezó tanulás vezérfonala legyen. A lista alapján tudja a diák megállapítani, hogy mely kompetenciái hiányoznak a leginkább. Az elérendố kompetenciákhoz minden esetben internet támogatta feladatokat rendeltünk. E projektjellegú feladatokat úgy terveztük

\footnotetext{
${ }^{8}$ A hálózati tanításban elốször az IBM LearningSpace programját használtuk. Lásd: http://edu.kando.hu/infotars/central.nsf, username: kurs, password: schule.) Ezt a - kölcsönbe kapott - platformot azonban magas költségei miatt nem tudtuk magunknak megvásárolni. Segítségül jött, hogy idóközben kifejlesztettek olyan szabadon letölthetô, nyílt forráskódú rendszereket, amelyek egyenrangúnak bizonyultak a professzionális cégek szoftverjeivel. (Lásd: www.moodle.com) Kurzusaink ezen a platformon: http://moodle.ktk.nyme.hu/
} 
meg, hogy megoldásuk lehetóleg a kívánt kompetencia megszerzéséhez vezessen. A projektekhez mindenütt csekklistákat, táblázatokat, folyamatábrákat és módszertani útmutatókat tartalmazó eszköztár, példatár, elérhetó online szakirodalom és nyomtatott szakirodalmi lista állt rendelkezésre. Ennek alapján a diák önállóan választhatta ki azokat a megoldandó feladatokat, amelyek egyrészt az ô előzetes tudása alapján megoldhatónak látszottak, másrészt várhatóan az ố hiányzó kompetenciáit fejleszthették. Az integrált tanulási környezetnek mindezek az elemei (kompetenciakatalógus, projektötletek, feladatok, információk, önértékelési és kommunikációs lehetôségek) arra szolgálnak, hogy a résztvevớk azt a bizonyos kompetenciát fejlesszék ki, amelyre saját cselekvési igényükból adódóan a leginkább motiváltak. Ez a koncepció a P. Dietrich által leírt alapelveket valósítja meg:

„A tanulás ebben az összefïggésben nem idóben és tartalmát tekintve egyaránt_lineárisan elóre megszervezett és algoritmizált folyamat, hanem messzemenöen önszervezó jellegú. Az ilyen típusú, nem strukturált, informális tanulás aะ internet sajátosságait tïkrözi. Annak ellenére, hogy a kurzuson tanárok (tutorok) segítik a munkát, a hiányæó kompetenciák meghatározása, a meglévoótudás definiálása és az ezeket a kompetenciákat fejlesz tó projektek és információk kiválasztása már a kurzus résztvevóinek feladata kell, hogy legyen. Ebben a térben a tanulás nem a tudás adott szervezetére épül, a tananyag nem tényállások pontosan elrendeæett és ellenörizhetố rendszere, hanem a résztvevoók kooperatív képzeletének és kollektiv kreativitásának terméke...A módszertani alapelvek középpontjában az a felismerés áll, hogy csak akkor lehet sikeresen tanulni, ha az ember átfogó képet kapott saját beállítottságairól és elóismereteiról.... Csak a felszínre hozottra lehet sikeresen épiteni, csak a megfelelóen felszínre hozottat lehet a tananyaggal célirányosan kiegésziteni és továbbfejleszteni."

Egyik első kísérletünk a vállalati tudásmenedzsment tanulási céllistájának (kompetencia-katalógusának) a létrehozása volt, a tudásmenedzsment-szeminárium egyik moduljaként.

A vállalati tudásmenedzsment (TM) kompetencialistája.

A hallgató legyen képes

1. vállalati TM-tervet készíteni;

2. saját tudását dokumentálni;

3. saját szellemi tókeértékét megállapítani;

4. saját tudásának dokumentáltságát értékelni;

5. megállapítani;

6. a vállalati tudástốke átadásának módozatairól listát készíteni;

7. dokumentálni;

8. tudásmenedzsmentet kínáló weblapot összeállítani;

9. a vállalat speciális tudástókéjét számba venni;

10. a világhálón vállalati tudásmenedzsment-programokat keresni;

11. tudásmenedzsmentet támogató szoftvereket kínáló cégek honlapjait értékelni;

12. saját cége számára tudásmenedzsmentet támogató szoftvert kiválasztani;

13. saját cége számára a forgalmazótól ajánlatot kérni;

14. és tapasztalatcsere-hálózatot megszervezni a vállalaton belül. 
A listához a következő feladatokat rendeltük:

1. Készítsen el egy vállalati tudásmenedzsment-tervet!

2. Állapítsa meg saját szellemi tôkéjének értékét!

3. Dokumentálja saját tudását!

4. Állapítsa meg, hogy milyen mértékben dokumentált a saját tudása!

5. Készítsen ellenőrző listát a tudástóke cseréjéról!

6. Állapítsa meg, hogy a vállalat tudástókéje hogyan dokumentált!

7. Állapítsa meg, hogy a saját vállalata hogyan szervezi a tudástóke cseréjét!

8. Készítsen honlapot egy olyan kisvállalkozás számára, amelyik tudásmenedzsmentet kínál!

9. Dokumentálja a vállalat speciális tudástókéjét!

10. Keressen vállalati tudásmenedzsment-programokat a világhálón!

11. Értékelje tudásmenedzsmentet támogató szoftvereket kínáló cégek honlapjait!

12. Válasszon ki saját cége számára tudásmenedzsmentet támogató szoftvert!

13. Kérjen ajánlatot saját cége számára a forgalmazótól!

14. Szervezze meg a vállalaton belüli tapasztalatcsere-hálózatot!

Példaként álljon itt két feladat:

Dokumentálja saját tudását!

- Készítsen el egy kompetencialistát arról, hogy milyen képességeket vesz igénybe a munkája! (Fogalmazza meg a képességeket ilyen formában: Képes vagyok... valamit... megcsinálni, például:

- angol nyelvú üzleti leveleket megfogalmazni

- az alkatrész-utánpótlást megszervezni

- egy konnektort beszerelni, stb.).

Példák a kompetencialistákra: asঞtalos, térinformatikus (Egy tudástérkép)

Segítségül: Személyes kompetencia-portfólió elkészítése ${ }^{9}$

Egy másik típusú feladat:

Keressen az interneten vállalati tudásmenedzsment-programokat!

- Készítsen rövid keresési naplót, ami tartalmazza a keresett címszavakat és bővítéseket!

- Készítsen egy linkgyújteményt azokról, amelyeknek a használatát el tudja képzelni a vállalatánál!

(A Google keresốprogram 2004. június 8-án a „tudásmenedzsment” hívớszóra 3660 magyar nyelvú találatot hozott.)

A kompetencia-katalógusnak ez az első változata még meglehetősen egydimenziósra sikerült. Még nem tartalmaz olyan elágazásokat, amelyek egy-egy komplex kompetencia alkompetenciáihoz - a mikrotanulási egységekhez - is elvezetnének. Az egyéni előzetes tudások figyelembe vételére is csak korlátozottan volt mód. Mindezek a hiányok azonban már elöre vetítették a kísérletezó és kutató munka követendö irányait.

${ }^{9}$ Lásd: http://kubus.net/moodle/eLearning/melleklet.htm 
Az „Információ, gazdaság, társadalom” címú alapkurzuson például negyedéves, gazdasági informatikára szakosodó hallgatók két csoportja vett részt: régió szakos és pénzügy szakos hallgatók. Számukra a globalizáció és a regionalizáció, illetve a globális pénzügyi rendszer témáiból állítottunk össze feladatokat, így legalább alapfokon építhettünk a (feltételezett) előzetes tudásra:

Feladatok a régió szakosoknak:

EU-pályázatírás

Az EU regionális politikája

A globalizáció problémái

Területfejlesztés

Globalizációellenes szervezetek honlapjának értékelése

Feladatcsoportok a pénzügyre szakosodott hallgatóknak

Globális pénzpiacok

E-banking

E-kereskedelem

Az oktatásszervező program módot adott rá, hogy minden diák lássa a másik feladatát, és azt kommentálhassa is. (A globalizációellenes szervezetek honlapjának elemzésével foglalkozó feladatot például közösen oldottuk meg, s az elsố gyújtéshez tíz további feladatmegoldás csatlakozott). A szándék a feladatmegoldások esetében is az volt, hogy a hallgatók egymás munkáit is értékeljék, rákérdező, kritikus, egymással a megoldási módokról kommunikáló kollektív tudástermelési aktusokba lépjenek. Ezt a szándékot is csak részben sikerült megvalósítani: a megoldások inkább kiegészítő-hozzáadó jellegúre sikeredtek, és kevésbé az érdemi tudáscserére és a közösen létrehozott tudásra irányultak.

Bonyolult kérdésnek bizonyult egyrészt az, hogy miképpen értékeljük ezeket a laza, nem algoritmizált, szituatí, projektjellegü tevékenységeket, másrésঞt pedig annak a ellentmondásnak a: áthidalása is, hogy a közös tudástermelés, a kooperatio munka eredményét egyénileg kellene értékelni.

A hagyományos vizsga tudvalevóleg a tudást, illetve annak egységes meglétét ellenôrzi, ugyanakkor a javak (ösztöndíj, kollégium, kitüntetések, állások) elosztásánál a differenciáló változó szerepét is betölti. ${ }^{10}$

A vizsga hatalmi eszköz is: a tanár ezzel kényszerítheti ki a szorgalmat, az órákon való részvételt és a lojalitást. (Foucault például a „Felügyelet és büntetés” c. könyvében elsốsorban a hatalomgyakorlás eszközeként elemzi az iskolai vizsgákat.) A hatalom

${ }^{10}$ „Max Weber szerint a speciális képzést nyújtó és speciális karriereket megnyitó, hierarchizált vizsgarendszer csak az újkori Európában jelent meg, egy bürokratikus szervezet szükségleteinek kifejlôdésével együtt, mivel ez a szervezet arra törekszik, hogy összehasonlítható és hierarchizált egyéneket helyezzen el a felkínált állások hierarchiájában" (Idézi Bourdieu 1971:374). Bernstein szerint ebben az ellenốrzési formában „Az értékelés rendszerében a hangsúly a tudás elért szintjén van, nem a tudáshoz vezetố utakon.” (Bernstein 1974:138.) 
egyik fontos eszköze a félelem. Ez a magyar egyetemi rendszerben meglehetốsen nagy helyet foglal el a tanulási motívumok között. (Ha azonban a félelem nagyobb az átlagos lámpaláznál, akkor bénítólag hat a tanulásra, a memóriára és a kreativitásra.)

Az ideáltipikus hipertanulás - változó idóben és utakkal - egyforma kimenetet bistosít. A hagyományos vizsgára mint az egységesítés és az ellenórzés eszközére tehát elvileg nincs szükség. Egy ilyen paradigma keretei között sokkal inkább azt kell ellenórizni, hogy biztositottak-e a variábilis tanulási utak és a rugalmas idókeretek. Mindez azonban gyökeresen ellentmond az egyetemi tanulás mai szervezeti rendjének.

Munkánkhoz - jellegéból fakadóan - leginkább a rövid szöveges értékelés illett volna, ami egyedileg minốsíti a végzett munkát. Az indexekbe viszont be kellett írni a jegyeket. Végül az egész féléves munka értékelése annak alapján történt, hogy milyen szinten vett részt a hallgató a közös munkában, melynek a fó elemei a következók voltak:

- saját tudástérkép elkészítése;

- az integrált oktatásszervezó program feladatai közül meghatározott számú feladat megoldása;

- keresési napló vezetése;

- a tárgy alapfogalmait tartalmazó lexikon szerkesztésében való részvétel.

Miután egyik fố feladatunk az információs társadalom elemzése volt, kézenfekvőnek látszott, hogy rákérdezzünk: Ha már annyit beszéltünk a tudásról, a személyes tudás reflexiójáról, nem lehetne-e saját hálózatba szervezett oktatási kísérletünket, saját tanulási szituációnk megváltozását közösen úgy elemezni, hogy az informatiæálódás társadalmi hatásait a saját tapasztalatainkon mérjük le? Olyan komplex és dinamikus problémákat, mint például a: egyetemi tudásreprezentáció, vagy a tudás mint speciális áru, vagy a globális hálózatok szerepe, meg lehet-e közeliteni a napi élettapasztalatok alapján?

\section{A saját életvilág mint a reflexió tárgya}

A tudástérképek elkészítésétôl tehát csak egy lépés vezetett addig a felismerésig, hogy mind a „Tudásgazdaságtan és tudásmenedzsment”, mind az „Informatika-gazdaság- társadalom” címú tantárgy szempontjából izgalmas kísérlet lenne saját szervezeti beágyazottságainkat, céljaink és lehetóségeink eltérését reflektálni, s igy saját léthelyzetïnk elemæésén keresztïl általánositottabb tudáshoz jutni.

A saját helyzetünkre vonatkozó lehetséges kérdések sora - vitáink alapján - így alakult ki:

- Miben változtak meg a tanulási feltételeink?

- Saját kereteink között mit jelent az önszervezó tanulás?

- Milyen új tanári és diákszerepekkel találkoztunk az információmenedzselésre alapozott oktatásban?

- Meg tudtuk-e szervezni saját szemináriumi kereteinkben a kooperatív tudásmenedzsmentet?

- Milyen típusú tudásokat szerezhettünk így? 
- Hogyan lehet a kollektív munkát egyénileg minôsíteni?

- Milyen egymás közötti viszonyok és milyen attitúdök alakultak ki az internettel támogatott tanulás kapcsán?

- Milyen áru a tudás?

- Hogyan fogadja be az egyetemi szervezet az új tanulási formákat?

- Mennyiben hasonlít az egyetem mint tudástermelő intézmény egy vállalathoz?

- Milyen általános társadalmi problémák tükröződnek jelen helyzetünkben?

- Melyek az internettel támogatott tanulás elónyei és hátrányai?

Az alapproblémák feltérképezését azzal kezdtük, hogy saját tapasztalatainkat és a szakirodalmat alapul véve, közös munkával öszeállítottunk egy táblázatot az internettel támogatott tanulás jellegzetességeiról:

\begin{tabular}{|c|c|}
\hline \multicolumn{2}{|c|}{ Az internettel támogatott tanulás jellegzetességei } \\
\hline Jellegzetességek & Problémák \\
\hline $\begin{array}{l}\text { A tanulási környezet minden komponensét (szerve- } \\
\text { zet, tananyagok, kommunikáció, adminisztráció, el- } \\
\text { lenőrzés) magába foglalja. }\end{array}$ & $\begin{array}{l}\text { Az internethez való hozzáférés lehetôsége még } \\
\text { nem túl széles, ráadásul drága. }\end{array}$ \\
\hline $\begin{array}{l}\text { Állandóan aktualizálható anyagok (szöveg, kép, } \\
\text { rajz, videofilm, hang) széles választékához biztosítja } \\
\text { a hozzáférést. }\end{array}$ & $\begin{array}{l}\text { Az alacsony átviteli sebesség korlátozza a multimé- } \\
\text { dia használatát. }\end{array}$ \\
\hline $\begin{array}{l}\text { Fejlett technológiával támogatja a sokoldalú kom- } \\
\text { munikációt, a keresést, a dokumentálást, az értéke- } \\
\text { lést, a feladatok automatikus létrehozását és értéke- } \\
\text { lését. }\end{array}$ & $\begin{array}{l}\text { A médium az elektronikus kommunikációs techni- } \\
\text { kák használata terén speciális kompetenciát kíván } \\
\text { meg. }\end{array}$ \\
\hline $\begin{array}{l}\text { Lehetôvé teszi a tanfolyami részvételt az idő és a } \\
\text { hely figyelmen kívül hagyásával. }\end{array}$ & $\begin{array}{l}\text { Az információs áradatban történó eligazodás egyéni } \\
\text { válogatási technikák és különféle kritériumok hasz- } \\
\text { nálatát kívánja meg. }\end{array}$ \\
\hline $\begin{array}{l}\text { A hipertext-struktúrákon keresztül lehetốséget ad } \\
\text { nemlineáris tanulási folyamat megvalósítására. }\end{array}$ & A kommunikáció egydimenziós. \\
\hline Támogatja az egyéni tanulási stílust és tempót. & $\begin{array}{l}\text { Hiányzik a személyes (face-to-face) kommunikáció } \\
\text { emocionális hatása. }\end{array}$ \\
\hline Segíti a tanulási folyamat önszervezését. & $\begin{array}{l}\text { Az éló előadás rögtönzése, spontaneitása hiányzik, } \\
\text { nincs meg a gondolatok helyszíni keletkezésének } \\
\text { és alakításának az élménye. }\end{array}$ \\
\hline $\begin{array}{l}\text { Az interaktív kommunikációs eszközök lehetốvé te- } \\
\text { szik a hálózatban való tanulást. }\end{array}$ & $\begin{array}{l}\text { Kevesebbet lehet gyakorolni az éló beszédet, az éló } \\
\text { vitát. }\end{array}$ \\
\hline $\begin{array}{l}\text { Az oktató személyes elốadói képességeire, karizma- } \\
\text { tikus hatására irányuló figyelem helyett biztosítja a } \\
\text { gondolatokra történố odafigyelést }\end{array}$ & $\begin{array}{l}\text { A képernyôn történô munkának ergonómiai határai } \\
\text { vannak. }\end{array}$ \\
\hline Lehetôvé teszi az egyéni elómenetel ellenórzését. & Sok link változik meg vagy túnik el. \\
\hline $\begin{array}{l}\text { Egyre jobb és jobb navigációs eszközök állnak ren- } \\
\text { delkezésre az internetes kereséshez. }\end{array}$ & $\begin{array}{l}\text { A vitafórumok sokszor átláthatatlanok, nem készül- } \\
\text { nek összefoglalók, a fontos és a nem fontos anyagok } \\
\text { keverednek. A tudásmenedzsment bonyolult szak- } \\
\text { feladattá válik. }\end{array}$ \\
\hline \multicolumn{2}{|l|}{$\begin{array}{l}\text { A feladatmegoldások és az online viták dokumen- } \\
\text { tálhatók, visszakereshetók és rendszerezhetók, s így } \\
\text { a közös tudásbázis mindenki által elérhetố részét } \\
\text { képezhetik. A tananyag struktúráját meg kell jele- } \\
\text { níteni, a kommunikáció szervezését el kell tervez- } \\
\text { ni. }\end{array}$} \\
\hline $\begin{array}{l}\text { Míg a hagyományos tankönyvek didaktikai céljai } \\
\text { gyakran kibogozhatatlanok, s a tankönyvek gyakran } \\
\text { nem tartalmaznak tanulási célokat, feladatokat, az } \\
\text { eLearning során a didaktikának explicitté kell válnia. }\end{array}$ & \\
\hline
\end{tabular}


Az interneten az aktuális információk, tudások és kontextusok olyan tárháza állt rendelkezésünkre, amelyet a hagyományos tankönyvek sohasem tudtak volna produkálni. A tankönyvek lineáris, viszonylag letisztázott, stabil (de éppen ezért sokszor elavult) ismeret-világával szemben itt egy gazdag, dinamikus, mindig megújuló, aktuális világ állt, amelyben viszont az eligazodás volt nehéz, a kontextualizáláshoz kellett speciális tudás. A hagyományos tanulási rutinnal és értékelési módokkal itt nem lehetett boldogulni. E folyamatban a keresés, a dokumentálás, a kontextuskeresés vált meghatározóvá. A diákszerep ez által megváltozott: az önálló tudásmenedzsment képessége vált a legértékesebb kompetenciává.

A tanári tudásmonopólium alapjaiban rendül meg azzal, hogy az internet az aktuális ismeretek olyan tárházát nyújtja, amellyel a legfelkészültebb oktató sem rendelkezhet. Ezzel a tanári hatalmi pozíció és identitás egyik fontos oszlopa omlott össze. A tanárnak új szerepet - a facilitátor, a moderátor, a tutor, a „coach” szerepét - kellett vállalnia: ${ }^{11}$ ebben a szerepben a tudásmenedzsment és az önszabályozás támogatásához szïkséges stratégiák (metakognició, metamotiváció) átadása vált a tevékenység fó elemévé.

Az ilyen tanulási szervezetnek egészen más sajátosságai vannak, mint a szokásos lineárisan szervezett tanfolyamnak, ahol egy pontosan meghatározott tanulási célt elóre definiált lépésekben szándékoznak elérni. A lineáris rendszerben a bemenet és az idófelhasználás egységes, bürokratikus és kötöttségekkel szabályozott, a kimeneti eredmény viszont -éppen az elözetes tudások kiülönbözösége miatt - nagyon eltéró. Az elvárt kimenettól való eltérést rossz osztályzattal, támogatás-elvonással büntetik.

„A hagyományos iskolamodellben egy kurzuson beliil adott témaköröket visænek végig, az órákat hetenként, tanteremben tartják és az órák közti idöszakra a hallgatók házi feladatot kapnak. Ez a lineáris tanulási modell, amit úgy alakitottak ki, hogy az információt meghatározott sorrendben közvetítse. Így elméletileg minden tanuló azonos ïtemben halad elöre, függettenül attól, hogy mi az érdeklödési teriiletiik, milyen elózetes tapasztalatokkal rendelkeznek, mihez van tehetségiik vagy milyen speciális igényeik vannak. A kuræus végén az osætályæatok jelzik, hogy a tanulók az adott, elốre meghatározott idố alatt milyen szintre jutottak."

írja Denning (2003:137-138)

Az önszervezó, internettel támogatott tanulási modell pontosan fordítva múködik. Mivel az elốzetes tudás szintjei és a konkrét cselekvési igények az egyes tanulók esetében nagyon különbözốek lehetnek, nem lehet minden résztvevő számára kötelezố vagy elvárható utakat elóírni. Emiatt a függó változókat a képzési idó és az elágazó, projektjellegú,

\footnotetext{
${ }^{11}$ Részlet a tanítást követố internetes naplómból: „A negyedéves gazdasági informatikai szakirányos hallgatóknak tartandó órára felkészültem a távmunka témájából. Összevont óránk van, három és fél óra, kitelik belóle az elméleti bevezetô. (Ez a csoport kezdte nemrég a munkát a LearningSpace programmal, amely nagyon sok konkrét, hálózati háttérrel támogatott feladatot kínál fel, de online megtalálható a szakirodalom is.) Bemegyek a laborba, a gépek már bekapcsolva, némelyek már dolgoznak. Rendezem a gondolataimat egy bevezetố kiselốadáshoz, de már hallom: „Tanár Úr!”. Hívnak az egyik géphez, hogy értelmezzük az egyik feladatot, amelyet valamelyik diák választott ki. Mások még nem ismerik ki magukat a programban: segítség kell. Egyenként odamegyek a gépekhez, együtt gondolkodunk a feladatokon, magyarázom a program használatát. Meglepetésemre többen választják a leginkább elméletigényes kérdéseket. Ténykedésem úgy megy át a prelegáló tanár szerepéból a moderátor, tutor, coach szerepébe, hogy szinte észre sem vesszuikk." Lásd: http://diakvallalkozas.ktk.nyme.hu/naplo.htm
} 
kollektív tudástermelésen alapuló tanulási utak jelentik. ${ }^{12}$ A kimenet ebben a módozatban egységes, mivel minden hallgató olyan jellegú elágazást választhat, amelyet saját elôzetes tudásának figyelembe vétele megkövetel, s annyi idốt fordíthat a tanulásra, amennyi saját tanulási stílusának, tempójának a legjobban megfelel. Az így szükségszerúen homogén kimeneti eredmények miatt a büntetés jellegú ellenôrzés, a hagyományos, merev vizsgaforma egyszerúen értelmét veszti.

Egy ilyen paradigmarendszerben az információáramoltatás és információmenedzselés olyan új formáiról és eszközeiról, a tudástermelés és a tudásforgalmazás olyan új módjairól van szó, amelyek az egyetemi szervezeti formák újragondolását, a múködési mód újjászervezését, a didaktika megváltoztatását követelik. Esetünkben a kitüzött célok és a megvalósulás közötti különbségek jó része abból fakadt, hogy kötött idôben, korlátozott erôforrások mellett kisérleteztünk olyan tanulási formákkal, amelyek rugalmas idóbeli kereteket, új együttmúköósi formákat, a tanulás, a tudás és a tudáselos:tás újradefiniálását kivánnák meg.

A felsőoktatás hagyományos szervezeti és hatalmi viszonyai az ilyen jellegú innovációt egyelöre még nem tudják befogadni.

Fekete László Az új gazdaság retorikája címú cikkében, amely az Élet és Irodalom címú hetilapban jelent meg, az új gazdasággal kapcsolatban jutott hasonló következtetésre:

„Az új gazdaság fogalmához valójában nem társult új gazdasági paradigma. Az új paradigma elemeit nyilvánvalóan a globális kommunikációs háló, a kommunikáló ember és a kommunikatív térben zajló gazdaságiés társadalmi tranzakciók jellegzetességei alkothatják. Szellemi kötóanyaga pedig a tudás, az innováció és az információ, amelyek - ha szabadon hozzáférhetöek, s megfelelnek a helyesség és a hitelesség minimális feltételeinek - a szükösségnek és a csökkenöhozadék törvényének ellentmondva, a böviilö lehetôségek sokaságát kínálják. A globális hálósati kommunikáció fejlódésének legfontosabb feltétele a tudás és aะ információ sæabad megosztása. Azonban a tulajdonosi jogok egyoldalí kiterjesz tése, új monopóliumok létrehozása és egyre eróteljesebb védelme jelzik, hogy a globális hálózati gazdaságban bizony a szúkösségre épiilö régi közgazdasági paradigma sæabályainak igyekeznek érvényt szerezni. Ennek következtében a kommunikáció szabadságában és az információ planetáris áramlásában rejló kreativ lehetóségek gyorsan és biztosan elenyésznek."

Saját élethelyzetünkre reflektálva ugyanarra a következtetésekre jutottunk, mint amit Kelen András állapít meg az informatizálódáshoz fưzôdố elvárások kritikája kapcsán:

Az uij gazdasággal kapcsolatban egyelöre gondolati forradalomról beszélhetiink, mert a történetben rejlö logikai követkerményeket igen hamar végiggondolták, ám igen kevés tevödött át a gyakorlatba és valósult meg e forradalmi potenciálból. (Kelen: 2004.)

Az eLearning gondolatilag szintén ragyogóan elô van készítve, majdnem mindent megírtak már róla, amit analitikusan ki lehet találni. Se szeri, se száma a potenciális szervezeti és didaktikai következményeket taglaló elemzéseknek és a (többnyire lelkes, optimista) jövóképeknek. A gyakorlat viszont általában szigetszerú esetekre korlátozó-

${ }^{12}$ Részletesebben lásd Denning 2003:137-138. 
dik és didaktikailag többnyire a lineáris tanítás technikai eszközökkel való meghosszabbítását jelenti. A minduntalan hangsúlyozott informatikai kihívás még vajmi kevés nyomot hagyott az egyetemek elosztási, hatalmi, szervezeti viszonyain. Szúcs Jenố terminológiájával kifejezve: $a$ „kis körök” alulról elinduló esetleges változásai még korántsem vezettek kumulatí szerkezeti változásokhoz. ${ }^{13}$

\section{A régi fogalmak fogságában?}

A változások bevezetéséhez természetesen elengedhetetlenül szükség van azokra a fogalmi keretekre, amelyek a gondolati elókészítés során keletkeztek, s amelyekben a változások egyáltalán elgondolhatók - akkor is, ha a realitás még ellenáll a fogalmaknak, és akkor is, ha az oktatási bürokrácia nyelvezetét még mindig elsôsorban az ipari társadalmakra jellemző zárt, hierarchikus fogalmi világ uralja. A két fogalmi világ egymás mellé állitása jelesheti az innovációk viziójának, implementációjának és ellenôr zésének irányát:

\begin{tabular}{|c|c|}
\hline $\begin{array}{l}\text { A zárt, hierarchikus oktatási környezet fogalmai } \\
\text { (ipari társadalom) }\end{array}$ & $\begin{array}{l}\text { A nyitott, kooperatív oktatási környezet fogalmai } \\
\text { (információs társadalom) }\end{array}$ \\
\hline Központi tanterv (a „tanterv-törvény”) & $\begin{array}{l}\text { Rugalmas kompetencia-portfóliók mint tanulási } \\
\text { célok }\end{array}$ \\
\hline Lineáris tanterv & Moduláris szervezés \\
\hline Tankönyv & Információs háttérkörnyezet a hálón \\
\hline Elôadás & Projekt-tanulás \\
\hline Tudásközlés „felülrôl” & $\begin{array}{l}\text { Kollektív tudáskeresés, tanácsadás a tudásmenedzs- } \\
\text { mentben }\end{array}$ \\
\hline Centralizált információelosztás & Párhuzamos információfeldolgozás \\
\hline Tanár & Tutor, moderátor, tanácsadó, coach, hálózatszervezô \\
\hline Tanulás & Kollektív tudásmenedzsment, hipertanulás \\
\hline Definíciós tudás & $\begin{array}{l}\text { Információ-menedzsment, keresés, dokumentálás, } \\
\text { kommunikációs tudás }\end{array}$ \\
\hline Érdemjegy, osztályzat & $\begin{array}{l}\text { Egyéni, de kollektívan összeállított } \\
\text { kompetencia-portfólió, tudástérkép }\end{array}$ \\
\hline Vizsga, „államvizsga”, beszámoltatás & $\begin{array}{l}\text { A tanár és a diák által közösen kitöltött } \\
\text { kompetencia-portfólió }\end{array}$ \\
\hline Vizsgaidőszak & $\begin{array}{l}\text { Önellenórzés, az eredményhez vezetô út közös } \\
\text { értékelése }\end{array}$ \\
\hline Zárthelyi dolgozatok & Szabad esszék \\
\hline Diploma & $\begin{array}{l}\text { Formális és informális úton szerzett kompetenciák } \\
\text { a kompetencia-portfólióban }\end{array}$ \\
\hline Instrukcionalista tanuláselmélet & Konstruktivista tanuláselmélet \\
\hline
\end{tabular}

Az, hogy a gondolkodásmódbeli, szervezeti és hatalmi akadályok ellenére mégiscsak belekezdhettünk a kísérletbe, több körülmény szerencsés összejátszásának köszönhetően volt lehetséges. Választható tárgyaink fölött nem lebegett ott a szigorlati ellenơrzés vagy az államvizsga Damoklész kardja. A fejlesztést külön projekt-keretból

${ }^{13}$ Az EU számára végzett egyik átfogó felmérés szerint a felsốoktatási intézmények $18 \%$-a használja integratív, innovatív módon az új kommunikációs technikákat.

Lásd: http://www.elearningeuropa.info/extras/pdf/virtual_models.pdf 
tudtuk finanszírozni. Rendelkezésünkre álltak a jól felszerelt informatikai laboratóriumok. Az egyetem informatikai központja segítókészen szolgáltatta a technikai hátteret. Az oktatás és a kutatás szabadságának jegyében kísérletünknek senki sem szabott adminisztratív korlátokat.

Ugyanakkor - elszigetelt csoportként - nem észleltük annak a jelét, hogy környezetünkre bármilyen hatást is gyakoroltunk volna. Kezdeti tapasztalatainkon alapuló innovációnk nem szerveződött innovatív intézmények hálózatába. Hiába kínáltuk fel társegyetemeinknek a tapasztalatokat, reakció nem volt. Ennek okait a következô tényezókben láttuk:

- Az oktatás szervezete, jogi szabályozása, óraszám elosztása és honorálása a hierarchikus szervezeti formákat részesíti elónyben.

- A tömegoktatás a taylorizálódásnak kedvez (amikor például 600 hallgatónak kell egyszerre zárthelyi dolgozatot írnia, ugyanazokkal a tesztkérdésekkel), a kooperatív hálózati munka ezzel szemben intenzív tutorálást igényel.

- A hálózati oktatásban a tartalmaknak és a módszereknek a reprezentált elózetes tudáshoz is igazodniuk kell. A jelenlegi szabványoktatásban viszont a szabványtantervhez kell igazodniuk a diákoknak a tanulás folyamatában, bármilyen elốzetes tudással jöttek is.

- A tudáshálózatok múködtetésének szervezeti, jogi, anyagi, didaktikai keretfeltételei nincsenek kidolgozva.

- Az internet által támogatott intenzív oktatási formák szervezeti, didaktikai nehézségei, előnyei és hátrányai még nem tudatosultak elég széles körben. Ez ellenálláshoz és a hagyományos formák apológiájához vezet.

\section{Hogyan tovább?}

A reflexiók végén felmerülhet a „Mi a teendô?” klasszikus kérdése is. Van-e más lehetốség, mint a felsoroltak ellenére tovább folytatni és hinni abban, hogy a helyi, kis hatókörú innovációk lassan-lassan, alulról terjeszkedve hatnak majd a szervezeti változásokra is, s ez majd a távoli jövốben minôségi ugrásokhoz vezet? ${ }^{14}$ Ha nincs közvetlen befolyásunk a nagy alrendszerek szerkezetét átalakító politikára, a törvényhozásra, akkor nyilvánvalóan csak ez a remény marad. A motiváció ezen az úton nem más, mint a kísérletezés és a tapasztalatszerzés öröme, vagy az, hogy az ilyesfajta kísérletek során szerzett tapasztalatok belépoót adhatnak a következő, netán az országhatárokon túlnyúló projektekhez is.

A kísérletezés másfél éve egyfajta speciális civil gondolkodásmódot érlelt meg bennem. Miért ne szervezhetném meg saját kezdeményezéssel a saját oktatási hálózatomat? A jelenlegi körülmények között technikailag semmi akadálya sincs, hogy hálózatba szervezốdjön az a szakmai kör, amely képes és hajlandó egy ilyen projektben együttmúködni. Kiinduló és motiváló hipotézisként elfogadtam, hogy ha a kísérlet tartalmas és a hálózat jól szervezett, a módszereknek elóbb-utóbb maguktól is terjedniük kell, s elóbb-utóbb az anyagi források is meg fognak nyílni. A kérdés csak az volt, hogy

\footnotetext{
${ }^{14}$ Nem éppen biztató perspektíva, hogy az Informatikai és Távközlési Minisztérium - amely két évre ígért támogatást a projekthez - az első év után megvonta azt.
} 
az állami egyetemi rendszer keretén belïl érdemes-e ezt megkísérelni, vagy inkább azon kivül. Miután ezt csak tapasztalati alapon lehet eldönteni, mindkét utat kezdeményeztem. Elhatároztam, hogy akkor is folytatom a helyi, kis léptékú kísérletezgetést, ha magyar támogatás egyelốre nincs hozzá. Másrészt európai projektekbe vittem a tapasztalatokat. Reméltem, hogy a megmerevedett egyetemi struktúrákat a mikroszintú lokális és a globális út kombinálásával egyidejúleg alulról és felülról is harapófogóba lehet venni, és hogy a versenytárs intézmények száma az intézményi mezo-szinten is szaporodjék, néhányad magammal megalapítottunk egy alternatív virtuális akadémiát. A legközelebbi beszámoló ezeknek a kísérleteknek a sorsáról adhat majd számot.

\section{Irodalom}

Chott, P. O. (1999): Wissensmanagement und Schule. Einführende Überlegungen zu einem Gegenwarts- und Zukunftsthema. SchulVerwaltung, 22. S. 306-310. http://www.schulpaed.de/pdf/a-wima2.pdf

Bernstein, Basil (1974): Az iskolai tudásanyag osztályozásáról és kereteiról (fraiming) In: Az iskola szociológiai problémái. KJK, 123-153).

Bourdieu, Pierre - Jean-Claude Passeron (1971): Egy illúzió vizsgálata. In: Az iskola szociológiai problémái. KJK, 371-402.

Denning, Peter. J. (2003): Ahogyan tanulni fogunk (In: Információs Társadalom, 2, 128-146.) A cikk egy elsó változata angolul: Business Design for a New University. http://cne.gmu.edu/pjd/PUBS/busdes.pdf

Dietrich, Peter: Lernen im Internet: Virtuelle Lehrveranstaltungen.

http://wwwhomes.uni-bielefeld.de/pdietric/inter_00.html

Fekete László (2004): Az új gazdaság retorikája. (In: Élet és Irodalom, 2004. 01. 16.) http://www.es.hu/pd/display.asp?channel=PUBLICISZTIKA0402\&article=20040112-0955-48PDMF)

Foucault, Michel (1990): Felïgyelet és büntetés. Budapest: Gondolat.

Kelen András (2004): Az új gazdaság és akik nem akarják. (In: Magyar Tudomány, 2.) http://www.matud.iif.hu/04feb/006.html

Klimkó Gábor: A tudás jellemzése. http://informatika.bkae.hu/root/web/db/kutatas.nsf/0/543ebf195e2749bbc1256dfb007 4897b/\$FILE/A\%20tudas\%20jellemzese\%20atadhatosaga\%20szerint.pdf

Pálvölgyi Mihály (2003): Információmenedzsment. Kísérleti tananyag. http://kit2.bdtf.hu/epub/hun/palvolgyi/im/index.htm

Szúcs Jenő (1983): Vázlat Európa három történeti régiójáról. Budapest: Magvetoó. 